\title{
A key to the identification of agglutinant and monothalamous foraminifera from Brazilian mangroves
}

\author{
Décio Semensatto ${ }^{1 *}$ \\ 1 Universidade Federal de São Paulo (Unifesp), Laboratory of Integrated Sciences (LablnSciences), Departamento de Ciências \\ Ambientais (Unidade José de Filippi - Rua Prof. Artur Riedel, n²75 - Jd. Eldorado - 09972-270 - Diadema - SP - Brazil) \\ *Corresponding author: decio.semensatto@unifesp.br
}

\section{AbStract}

Identification keys are essential tools to guarantee higher precision during the taxonomic work. However, such keys are rare for foraminifera and often encompass a restrict group of species from a given geographic region. Thus, the taxonomic identification process usually occurs by visual comparison and by verifying the description of morphological attributes, which requires the previous knowledge of the species before identification. The use of an identification key seeks to help in this crucial step and contribute to the best taxonomic precision, which errors may propagate in the subsequent analyses that are supported by estimations on species richness and abundances. Moreover, it constitutes an extra tool to assist in the training of new researchers. This paper brings an identification key for agglutinant and monothalamous foraminifera from Brazilian mangroves, considering 50 genera and 91 species.

Descriptors: Foraminifera, Systematics, Mangrove, Identification key.

\section{INTRODUCTION}

Accurate taxonomic identification is a crucial step in research involving community ecology. Taxonomic errors can propagate along a chain of analysis, when ecological indices, transfer functions and statistical calculations differentiate taxonomic groups, and even over time if a particular work becomes a reference for other researchers to identify species ( $\mathrm{Wu}$, 1982; Bortolus, 2008; Payne et al., 2011; Vink et al., 2012). Such consequences can lead to inaccurate or erroneous interpretations of recent and past environmental scenarios and may lead to improper decisions about environmental management when they are

Submitted on: 29/October/2019

Approved on: 8/April/2020

Associate Editor: Felipe Toledo

Editor: Rubens M. Lopes

(c) (i) 02020 The authors. This is an open access article distributed under the terms of the Creative Commons license. based on indicators such as species richness, abundance and diversity. In the case of using indexes such as Shannon $\left(\mathrm{H}^{\prime}\right)$, both underestimation and overestimation of rare species significantly impact the value of diversity, as this index applies the logarithm on relative abundance and thus reduces the algebraic difference between dominant species and rare species (Magurran and McGill, 2011).

The use of recent foraminifera as bioindicators has been proposed for several purposes (Scott et al., 2001; Yanko et al., 2003; Murray, 2006; Alve et al., 2009; Sabean et al., 2009; Frontalini et al., 2009; Bouchet et al., 2012; Alve et al., 2019). Although some species are recognized relatively easily, there are cases where only the detailed analysis of morphological attributes will ensure correct identification. Recently, the development of environmental DNA (eDNA) detection tools has pointed to new challenges in the field of taxonomy for foraminiferal species identification and estimating diversity (Pawlowski et al., 2014, 2016; 
Siemensma et al., 2017). However, in most cases, the identification of foraminifera species is based on the visual comparison between the test and images published in the literature, in addition to the observation of specific morphological characteristics described in detail in some classical references. However, these references do not provide species identification keys, and consulting their content usually requires preidentification of the test in question.

Identification keys are handy tools in training researchers for taxonomy as well as for harmonizing species identification/taxonomic levels. Although certain areas of knowledge widely use these tools, such as Botany, there are few keys available about foraminifera (e.g., Todd and Low, 1981; Clark and Patterson, 1993; Revets, 2005). In this perspective, the present work proposes a key for the identification of Brazilian mangrove agglutinant and monothalamous foraminifera, aiming to contribute to the harmonization between research groups and results in the identification of species, as well as assisting in the training of new researchers.

\section{MATERIAL AND METHODS}

The construction of the identification key started from the creation of a database of occurrence of agglutinant and monothalamous foraminifera species from Brazilian mangroves. Therefore, it includes only articles published in national and international scientific journals, raised from searches in the main platforms of scientific publication available in Periódicos Capes (www. periodicos.capes.gov.br), totaling 19 productions (17 articles, one book chapter and one seminar paper in conference proceedings). The species list reported only for samples collected at mangroves in these papers was compiled, and then the key was constructed to the genus level. For each genus it is also listed the species respectively found in Brazilian mangroves. The construction of the key up to the genus aimed to make it less complex, and the identification of the species should be accompanied by consulting the literature where there are descriptions and images, in addition to the fact that some genera are represented by only one species.

Given that the purpose of this key is to help the researcher correctly identify a species based on the visualization of the test, the key refers to only the morphological attributes that are visible and distinguishable under the stereomicroscope. The organization of the morphological attributes of the species is based on compilation and systematic work of foraminifera that serve as reference for several works (e.g. Ellis and Messina, 1940 et seq.; Closs, 1962; Boltovskoy et al., 1980; Loeblich and Tappan, 1988; Brönnimann et al., 1992; Hayward and Hollis, 1994; Hayward et al., 1999; Scott et al., 2001; Sen Gupta, 2003; Debenay, 2013). In addition to the identification key, species systematics was also organized with hierarchical levels harmonized with the World Foraminifera Database platform (Hayward et al., 2019).

\section{THE IDENTIFICATION KEY}

The key includes 50 genera, which in turn covers 91 species. The key is binary-type, i.e., only two answers are possible and are mutually exclusive. The identification pathways follow steps referenced with numbers. Each step can result in the identification of a genus (so, the identification pathway finishes) or in the indication of the next step to be consulted. In the case of the announced feature coincides with that observed by the researcher, the pathway indicate: "go to'number"'. The entry number in the step is followed by another in parentheses, which indicates which is the previous step to reach that point of the pathway (e.g., '36 (32)': indicates that the researcher has reached step \#36 from step \#32). Thus, if the identification finishes and does not match the test under observation, it is possible to return to the previous steps and look for alternatives. The images of most of species can be found in plates II, III and III (see Systematics section).

1. Uncoiled test (uniserial, biserial or triserial arrangement) - go to $\mathbf{2}$.

Coiled test (trochospiral, planispiral or streptospiral. The coiled portion can be followed by a uniserial, biserial or triserial portion) - go to 26 .

2 (1). Unilocular test - go to 3.

Multilocular test - go to 14 .

3 (2). Test without wall projections - go to 4.

Test with wall projections - go to 9.

4 (3). Test rectilinear tubular - genus Bahianotubus.

Test with another shape - go to 5 .

5 (4). Test fusiform - genus Bahianofusus.

Test with another shape - go to 6 .

6 (5). Globular test - genus Blysmasphaera. Test with another shape - go to 7 . 

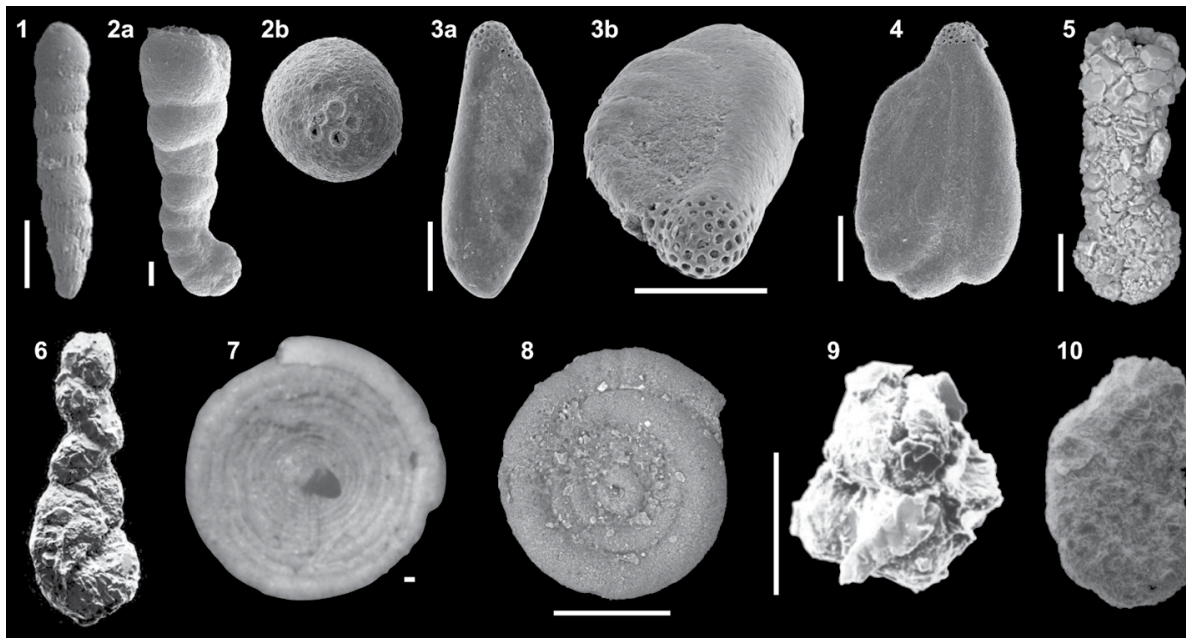

8
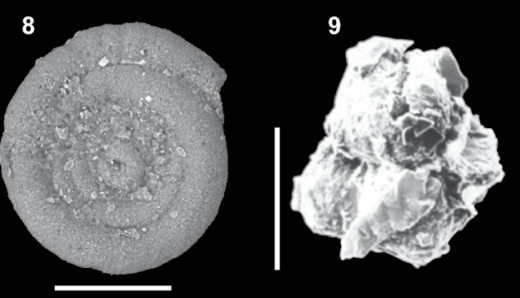

10
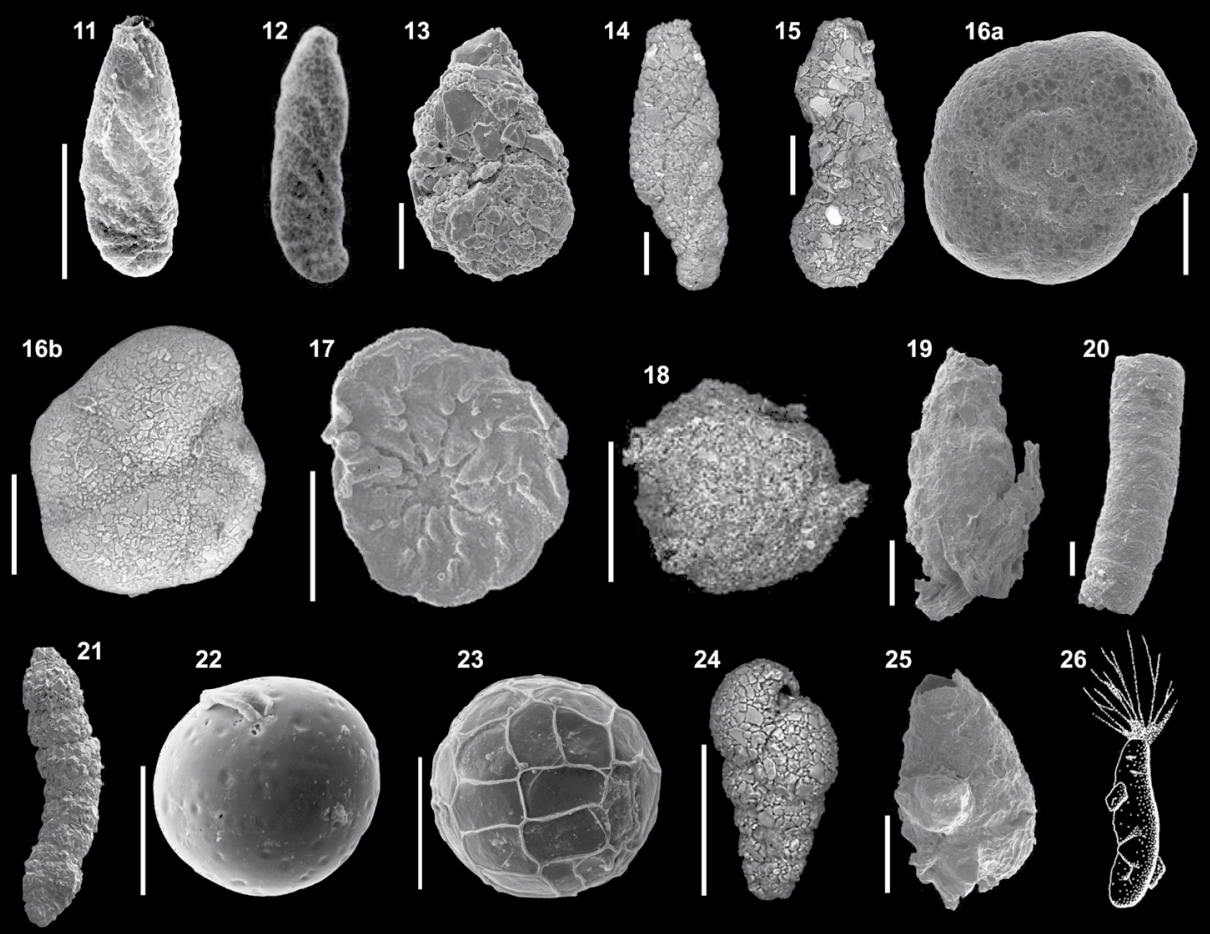

22
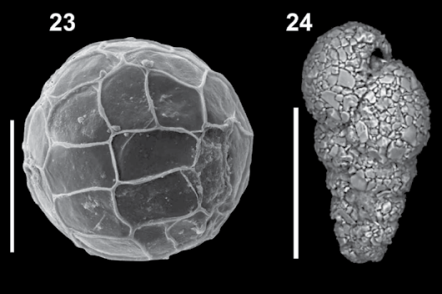

25

26
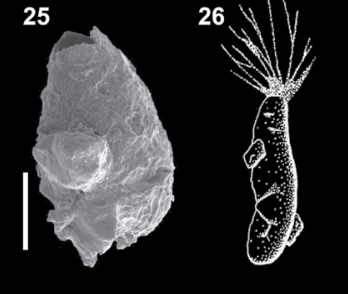

Plate I. 1. Acostata mariae. Image adapted from Laut et al. (2017), PI. I, Figure 1. 2a. Acupeina triperforata. Image adapted from Laut et al. (2012), Figure 17, II. 20. 2b. Acupeina triperforata. Aperture view. Image adapted from Santa-Cruz (2004), PI. VII, Figure 2. 3a,b. Ammoastuta inepta. Test collected at the intertidal zone from the São Francisco River delta, Brazil, Recent. Image from the author's collection. 4. Ammoastuta salsa. Image adapted from Santa-Cruz (2004), PI. VI, Figure 5. 5. Ammobaculites exiguus. Image adapted from Semensatto Jr. \& Dias-Brito (2004), Figure 4, Il. 6. 6. Ammobaculoides sp. (species illustrated: Ammobaculoides troelseni) Image adapted from Brönnimann and Dias-Brito (1982), Pl. 1, Figure 5. 2. 7. Ammodiscoides turbinatus. Image adapted from LeRoy \& Hodgkinson (1975), Pl. 2, Figure 14. 8. Ammodiscus sp. Image adapted from Semensatto-Jr. \& Dias-Brito (2004), Figure 4, II. 2. 9. Ammopemphix sp. (species illustrated: Ammopemphix?). Image adapted from Barbosa et al. (2005), PI. 3, Figure 6. 10. Ammoscalaria sp. Image adapted from Disaró (2006), Pl. 1, Figure 10. 11. Ammotium cassis. Test collected at the intertidal zone from the São Francisco River delta, Brazil, Recent. Image from the author's collection. 12. Ammotium directum. Image adapted from Disaró (2006), PI. 1, Figure 12. 13. Ammotium morenoi. Test collected at the intertidal zone from the São Francisco River delta, Brazil, Recent. Image from the author's collection. 14. Ammotium pseudocassis. Image adapted from Semensatto Jr. \& Dias-Brito (2004), Figure 4, II. 11. 15. Ammotium salsum. Test collected at the intertidal zone from the São Francisco River delta, Brazil, Recent. Image from the author's collection. 16a,b. Arenoparrella mexicana. Test collected at the intertidal zone from the São Francisco River delta, Brazil, Recent. 17. Asterotrochammina sp. (species illustrated: Asterotrochammina camposi). Image adapted from Rudorff (2008), PI. II, Figure 25. 18. Astrammina rara. Test collected at the mangrove from Ilha do Cardoso, Brazil, Recent. Image from the author's collection. 19. Bahianofusus pontei. Image adapted from Laut et al. (2012), Figure 17, II. 2 (Bahianofusos pontoni). 20. Bahianotubus salvadorensis. Image adapted from Laut et al. (2012), Figure 17, II. 3. 21. Bigenerina sp. (species illustrated: Bigenerina nodosaria). Image adapted from Milker and Schmiedl (2012), Figure 10, Il. 11. 22. Blysmasphaera brasiliensis. Image adapted from Semensatto et al. (2008), PI. I, Figure B. 23. Blysmasphaera broennimanni. Image adapted from Semensatto et al. (2008), PI. I, Figure C. 24. Caronia exilis. Test collected at the mangrove from Bertioga Channel, Brazil, Recent. Image from the author's collection. 25. Chitinosaccus guaratibaensis. Image adapted from Laut et al. (2012), Figure 17, II. 1. 26. Chitinosaccus zuluensis. Image adapted from Smitter (1956), Figure 1, II. D. 


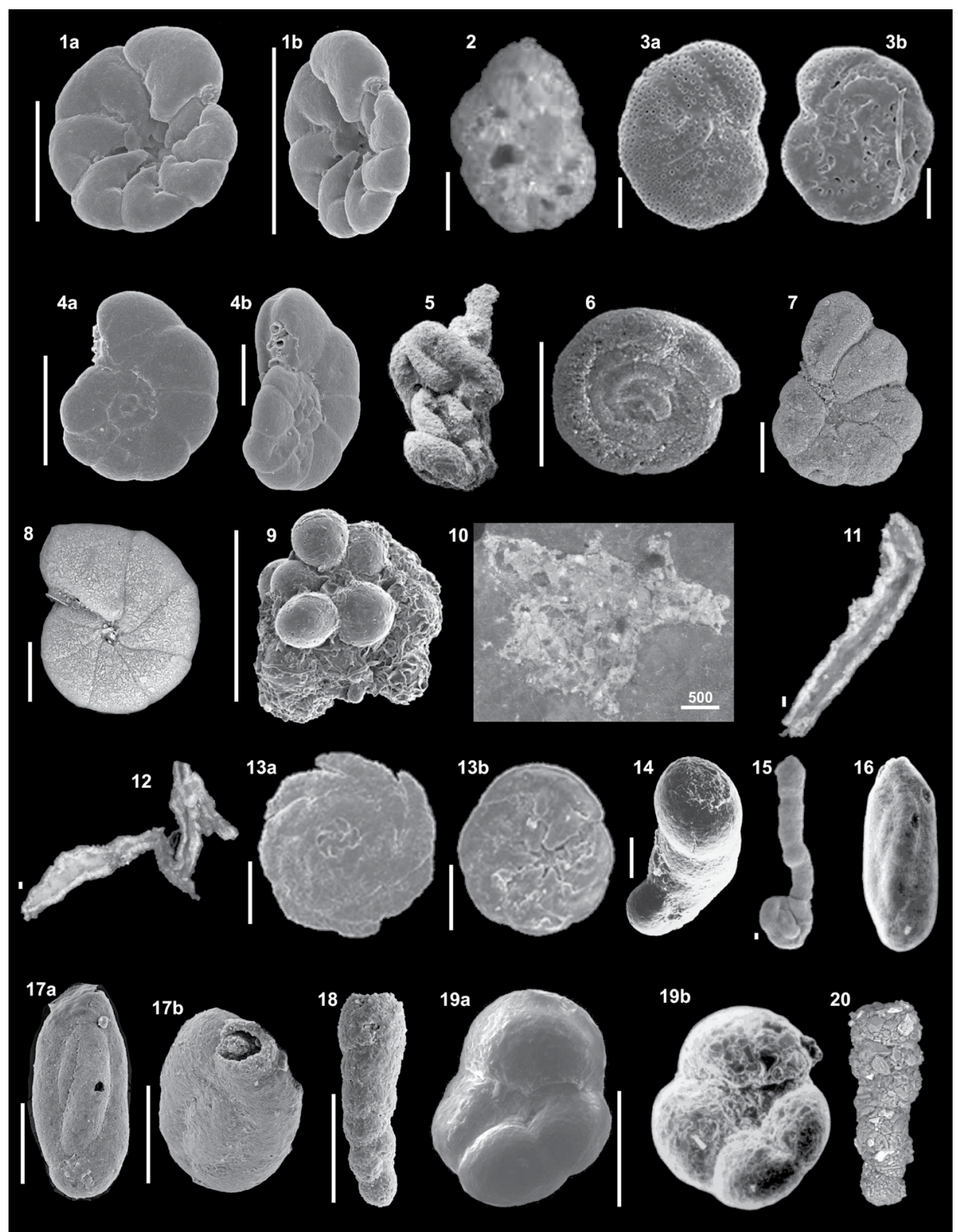

Plate II. 1a,b. Deuterammina sp. Test collected at tidal marshes, Portugal, Recent. Image courtesy of Prof. Dr. Francisco Fatela and Dr. João Moreno. 2. Discammina sp. Image adapted from Panchang \& Nigan (2014), Pl.1, Figure 18. 3a,b. Discorinopsis aguayoi. Image adapted from Camacho et al. (2015), Figure 3, Ils. 26, 27. 4a,b. Entzia macrescens. Test collected at tidal marshes, Portugal, Recent. Image courtesy of Prof. Dr. Francisco Fatela and Dr. João Moreno (Jadammina macrescens). 5. "Glomospira” glomerata. Image adapted from Galeotti et al. (2004), Pl. 2, Il. 7. 6. Glomospira gordialis. Test collected at the intertidal zone from Curimataú River, Brazil, Recent. Image from the author's collection. 7. Haplophragmoides manilaensis. Test collected at the intertidal zone from the São Francisco River delta, Brazil, Recent. Image from the author's collection. 8. Haplophragmoides wilberti. Test collected at the intertidal zone from the São Francisco River delta, Brazil, Recent. Image from the author's collection. 9. Hemisphaerammina bradyi. Image adapted from Waśkowska and Kaminski (2019), Figure 4, Il. G. 10-12. Iridia diaphana. Image adapted from Kaminski et al. (2008), Pl., 7, Figures 7, 9, 10. 13a,b. Lepidodeuterammina ochracea. Image adapted from Camacho et al. (2015), Figure 3, Ils. 5, 6. 14. Lituola sp. Image adapted from Barbosa et al. (2005), Pl. I, Figure 23. 15. Lituotuba sp. (species illustrated: Lituotuba lituiformis). Image adapted from Laut et al., (2014), Figure 9, FB1, Il. D. 16. Miliammina earlandi. Image adapted from Disaró (2006), Pl. 2, Figure 16. 17a,b. Miliammina fusca. Test collected at the intertidal zone from the São Francisco River delta, Brazil, Recent. Image from the author's collection. 18. Monotalea salsa. Image adapted from Semensatto-Jr. \& Dias-Brito (2004), Figure 4, Il. 8. 19a,b. Paratrochammina clossi. Image adapted from Laut et al. (2017), Pl. V, Figure B, and Disaró (2006), Pl. II, Figure p. 20. Polysaccammina hyperhalina. Image adapted from Semensatto-Jr. \& Dias-Brito (2004), Figure 4, Il. 13. 


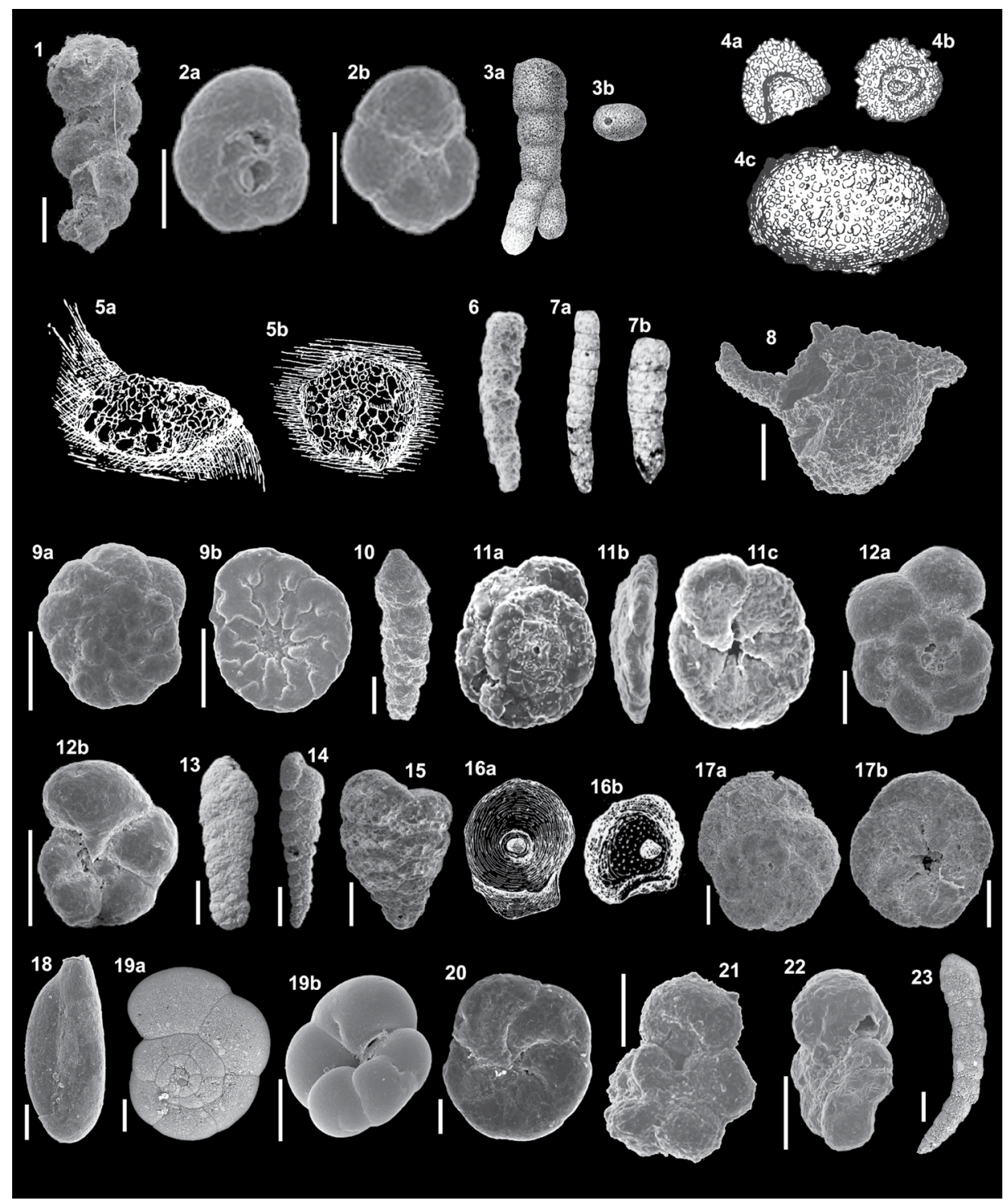

Plate III. 1. Polysaccammina ipohalina. Image adapted from Santa-Cruz (2004), Pl. I, Figure 2. 2a,b. Portatrochammina sp. Image adapted from Camacho et al. (2015), Figure 3, Ils. 9, 10. 3a,b. Protoschista findens. Image adapted from Jones (1994), Pl. 32, Figures 10A and B. 4a-c. Psammosphaera frankei. Image adapted from Rhumbler (1935), Pl. 5, Figures 4A, B and C. 5a,b. Psammosphaera fusca f. adhaerens. Image adapted from Rhumbler (1935), Pl. 9, Figures 5A and B. 6. Pseudoclavulina curta. Image adapted from Disaró (2006), Pl. II, Figure 6. 7a,b. Pseudoclavulina gracilis. Image adapted from Cushman \& Todd (1948), P1. 7, Figures 17A and B. 8. Pseudothurammina limnetis. Image adapted from Encarnação (2012), Figure 9.3. 9a,b. Remaneica sp. (species illustrated: Remaneica helgolandica). Image adapted from Encarnação (2012), Figures 9A and B, Ils. 2, 3. 10. Reophax nana. Image adapted from Rudorff (2008), Pl. 1, Figure 8. 11a-c. Rotaliammina sp. (species illustrated: Rotaliammina squamiformis). Adapted from Loeblich \& Tappan (1994), Pl. 24, Figures 11A, B and C. 12a,b. Siphotrochammina lobata. Image adapted from Santa-Cruz (2004), Pl. VIII, Figure 1, Pl. VII, Figure 6. 13. Spiroplectammina biformis. Image adapted from Nathan et al. (2014), Figure 23, Il. 7. 14. Textularia earlandi. Test collected at the intertidal zone from Curimataú River, Brazil, Recent. Image from the author's collection. 15. Textularia gramen. Image adapted from Zerfass et al. (2006), Figure 6, Il. 5. 16a,b. Tholosina centroforata. Image adapted from Rhumbler (1935), Pl. 4, Figures 16A and B. 17a,b. Tiphotrocha comprimata. Image adapted from Santa-Cruz (2004), Pl. VIII, Figures 17A and B. 18. Trilocularena patensis. Test collected at the intertidal zone from the São Francisco River delta, Brazil, Recent. Image from the author's collection. 19a. Trochammina inflata. Test collected at the intertidal zone from the São Francisco River delta, Brazil, Recent. Image from the author's collection. 19b. Trochammina inflata. Test collected at tidal marshes, Portugal, Recent. Image courtesy of Prof. Dr. Francisco Fatela and Dr. João Moreno. 20. Trochammina squamata. Image adapted from Laut et al. (2007), Pl. I, Figure 14. 21. Trochamminita irregularis. Image adapted from Encarnação (2012), Figure 9.6. 22. Trochamminita salsa. Test collected at tidal marshes, Portugal, Recent. Image courtesy of Prof. Dr. Francisco Fatela and Dr. João Moreno. 23. Warrenita palustris. Test collected at the intertidal zone from the São Francisco River delta, Brazil, Recent. Image from the author's collection. 
7 (6). Test a saclike chamber with a rounded terminal aperture - genus Chitinosaccus.

Test hemispherical, with or without apparent aperture - go to 8 .

8 (7). No apparent aperture - genus Hemisphaerammina.

Two or more apertures just above the base of the test - genus Tholosina.

9 (3). Test free - go to 10.

Test attached - go to 12 .

10 (9). Test without projections, large (up to $6 \mathrm{~mm})$, consisting of one to several loosely joined spherical chambers - genus Psammosphaera.

Test with projections - go to 11.

11 (10). Smooth and homogeneous wall with numerous tubular extensions and with sand grains larger than the thickness of the wall - genus Astrammina.

Wall finely agglutinated with silt grains and with up to five mammillae irregular projections - genus

\section{Pseudothurammina.}

12 (9). Wall proteinaceous - genus Iridia.

Wall agglutinated - go to 13 .

13 (12). Wall thick, of agglutinated fine sand, sponge spicules, and other foraminiferal tests - genus Crithionina.

Wall thin, flexible - genus Pseudothurammina.

14 (2). Elongate chambers and cribrate aperture - genus Ammoastuta.

Chambers with other forms - go to 15.

15 (14). Biserial portion at least in one stage - go to 16.

Test without biserial portion - go to 19.

16 (15). Test with initial biserial portion followed by a uniserial portion - go to 17.

Test with other features - go to 18.

17 (16). Initial portion acute, aperture evaginated - genus Bigenerina.

Initial portion rounded, aperture terminal rounded - genus Monotalea.
18 (16). Test with a tiny initial triserial portion followed by a biserial portion - genus Textularia.

Test only biserial - genus Caronia.

19 (15). Test arched with aperture an elongate slit at the terminal end of the test - genus Warrenita.

Test not arched - go to 20.

20 (19). Chambers with irregular shape - genus Polysaccammina.

Chambers with regular shape - go to 21 .

21 (20). Loosely joined spherical chambers - genus Psammosphaera.

Chambers with another shape - go to 22.

22 (21). Test with two or more branching uniserial stages - genus Protoschista.

Test without branching series - go to 23.

23 (22). Hemispherical chambers - genus Ammopemphix.

Chambers with another format - go to 24 .

24 (23). Early-stage triserial and triangular, then uniserial with cylindrical chambers - genus Pseudoclavulina.

Test only uniserial - go to $\mathbf{2 5}$.

25 (24). Aperture rounded - genus Reophax.

Aperture lenticular - genus Acostata.

26 (1). Test planispiral (can be initially streptospiral or followed by a uniserial or biserial portion) go to 27.

Another coil - go to 39.

27 (26). Test discoid - go to 28.

Test not discoid - go to $\mathbf{3 0 .}$

28 (27). Initial portion streptospiral - genus Glomospira.

Initial portion no-streptospiral - go to 29.

29 (28). Test with a "w" outline in the lateral section - genus Ammodiscoides.

Test without "w" outline - genus Ammodiscus.

30 (27). Test with a uniserial or biserial portion go to 31 . 
Test without a uniserial or biserial portion - go to 36.

31 (30). Initial planispiral with biserial followed by uniserial portion - genus Ammobaculoides.

Another arrangement - go to $\mathbf{3 2}$

32 (31). Only biserial portion - genus Spiroplectammina.

Only uniserial portion - go to 33.

33 (32). Sutures rather indistinct - go to 34.

Sutures distinct - go to 35 .

34 (33). Later part with tubular chambers - genus Lituotuba.

Later part with short and broad chambers - genus Ammoscalaria.

35 (33). Sutures oblique in the uniserial portion genus Ammotium.

Sutures not oblique in the uniserial portion - go to 36 .

36 (35). Single aperture - genus Ammobaculites. Aperture with several pores - genus Lituola.

37 (30). Aperture an interiomarginal arch evaginated at the base of the final chamber - genus - Haplophragmoides.

Other aperture - go to 38.

38 (37). Chambers and sutures not distinct - genus Discammina.

Globular chambers distinct, irregularly arranged, depressed sutures - genus Trochamminita.

39 (26). Trochospiral test - go to 40.

Another coil - go to 52.

40 (39). Test plan-convex or concave-convex - go to 41 .

Test not plan-convex nor concave-convex - go to 45.

41 (40). Chambers with large pores in the center and edges - genus Discorinopsis.

Chambers without pores - go to $\mathbf{4 2}$.

42 (41). Chambers extending back at the periphery - genus Lepidodeuterammina.
Chambers not extending back at the periphery go to 43.

43 (42). Aperture interiomarginal and extraumbilical with secondary openings - genus Asterotrochammina.

Other aperture - go to 44.

44 (43). Aperture a low interiormarginal arch in the final septal face - genus Portatrochammina.

Aperture a small rounded interiomarginal extraumbilical opening - genus Remaneica.

45 (40). Slit-like aperture areal to interiomarginal-genus Arenoparrella.

Aperture with another shape - go to 46.

46 (45). Supplementary areal apertures - genus Entzia.

Without supplementary apertures - go to 47 .

47 (46). Siphon-like aperture, chambers rounded - genus Siphotrochammina.

Aperture with another shape - go to 48.

48 (47). Aperture umbilical - genus Rotaliammina.

Aperture umbilical-extraumbilical - go to 49.

49 (48). Chambers distinctly "T"-shaped in the umbilical side - genus Tiphotrocha.

Chamber with other features - go to $\mathbf{5 0 .}$

50 (49). Secondary aperture at the umbilical tip genus Deuterammina.

Without secondary aperture - go to 51 .

51 (50). Aperture with a lip-genus Trochammina. Aperture without a lip-genus Paratrochammina.

52 (39). Milioline coil - go to 53.

Another coil - go to 54 .

53 (52). Triloculine test - genus Trilocularena. Quinqueloculine test - genus Miliammina.

54 (52). Initial portion streptospiral followed by a uniserial portion - genus Acupeina.

Initial portion streptospiral followed by a planispiral portion - genus Glomospira. 


\section{SYSTEMATICS}

Phylum FORAMINIFERA

Class MONOTHALAMEA Haeckel, 1862 (Pawlowski, Holzmann and Tyska, 2013).

Order ASTRORHIZIDA Lankester, 1885.

Suborder ASTRORHIZINA Lankester, 1885.

Superfamily ASTRORHIZOIDEA Brady, 1881.

Family RHABDAMMINIDAE Brady, 1884.

Subfamily BATHYSIPHONINAE Avnimelech, 1952.

Genus Bahianotubus Brönnimann, Zaninetti and Moura, 1979.

Bahianotubus salvadorensis Brönnimann, Zaninetti and Moura,

1979, Pl. I, Figure 20.

Suborder SACCAMMININA Lankester, 1885.

Superfamily PSAMMOSPHAEROIDEA Haeckel, 1894.

Family LACUSTRINELLIDAE Mikhalevic, 1995.

Genus Ammopemphix Loeblich, 1952.

1931 Urnula Wiesner.

1952 Ammopemphix Loeblich.

Ammopemphix sp., PI. I, Figure 9.

Family PSAMMOSPHAERIDAE Haeckel, 1894.

Subfamily PSAMMOSPHAERINAE Haeckel, 1894.

Genus Psammosphaera Schulze, 1875.

1875 Psammosphaera Schulze.

1913 Arphammosphaerum Rhumbler.

1935 Psammella Rhumbler.

1939 Arenosphaera Shchendrina.

Psammosphaera frankei (Rhumbler, 1935), PI. III, Figures 4A, B and C. 1935 Psammella frankei Rhumbler.

2018 Psammosphaera frankei Hayward, Le Coze and Gross.

Psammosphaera fusca f. adhaerens Rhumbler, 1935, PI. III,

Figures $5 \mathrm{~A}$ and $\mathrm{B}$.

1935 Psammosphaera fusca f. adhaerens Rhumbler.

1977 Psammosphaera adherens (Rhumbler) Zaninetti, Brönnimann, Beurlen and Moura.

Superfamily SACCAMMINOIDEA Brady, 1884.

Family CRITHIONINIDAE Hofker, 1972.

Subfamily CRITHIONININAE Hofker, 1972.

Genus Crithionina Goës, 1894.

1894 Crithionina Goës.

1913 Arcrithionum Rhumbler.

Crithionina mamila Goës, 1894.

Crithionina sp.

Family SACCAMMINIDAE Brady, 1884.

Subfamily THOLOSININAE.

Genus Iridia Heron-Allen and Earland, 1914. 
Iridia diaphana Heron-Allen and Earland, 1914, PI. II, Figures 10-12. 1914 Iridia diaphana Heron-Allen and Earland. 1921 Iridia diaphana (Heron-Allen and Earland) Cushman. 1935 Iridia diaphana (Heron-Allen and Earland) Doyle.

Iridia sp.

Genus Tholosina Rhumbler, 1935.

Tholosina centroforata Rhumbler, 1935, PI. III, Figures 16A and B. Subfamily THURAMMININAE Miklukho-Maklay, 1963.

Genus Astrammina Rhumbler, 1931.

1931 Astrammina Rhumbler.

1932 Armorella Heron-Allen and Earland.

Astrammina rara Rhumbler, 1931, PI. I, Figure 18.

1871 Astrammina rara Rhumbler, 1931.

1932 Armorella sphaerica Heron-Allen and Earland.

1977 Astrammina sphaerica (Heron-Allen and Earland) Zaninetti,

Brönnimann, Beurlen and Moura.

1980 Astrammina sphaerica (Heron-Allen and Earland) Lena.

1986 Astrammina sphaerica (Heron-Allen and Earland) Schröder.

2013 Armorella sphaerica (Heron-Allen and Earland) Debenay.

Genus Bahianofusus Brönnimann, Zaninetti and Moura, 1979.

Bahianofusus pontei Brönnimann, Zaninetti and Moura, 1979, Pl.

I, Figure 19.

Genus Pseudothurammina (Scott, Medioli and Williamson, 1981).

Pseudothurammina limnetis (Scott and Medioli, 1980), PI. III,

Figure 8.

1980 Thurammina limnetis Scott and Medioli.

1981 Pseudothurammina limnetis (Scott and Medioli) Scott, Medioli and

Williamson.

1994 Pseudothurammina limnetis (Scott and Medioli) Hayward and Hollis. 1999 Pseudothurammina limnetis (Scott and Medioli) Hayward, Grenfell,

Reid and Hayward.

2013 Pseudothurammina limnetis (Scott and Medioli) Debenay.

Family STEGNAMMINIDAE Moreman, 1930.

Subfamily HEMISPHAERAMMININAE Loeblich and Tappan, 1961.

Genus Hemisphaerammina Loeblich and Tappan, 1957.

Hemisphaerammina bradyi Loeblich and Tappan, 1957, PI. II,

Figure 9.

Order ALLOGROMIIDA Loeblich and Tappan, 1961.

Family ALLOGROMIIDAE Rhumbler, 1904.

Genus Blysmasphaera Brönnimann, 1988.

Blysmasphaera brasiliensis Brönnimann, 1988, PI. I, Figure 22.

Blysmasphaera broennimanni Semensatto, Oliveira and Dias-Brito, 2008,

PI. I, Figure 23.

Subfamily ALLOGROMIINAE Rhumbler, 1904.

Genus Chitinosaccus Smitter, 1956.

Chitinosaccus guaratibaensis Brönnimann, Zaninetti and Moura, 
1979, Pl. I, Figure 25.

Chitinosaccus zuluensis Smitter, 1956, PI. I, Figure 26.

Chitinosaccus sp.

Class GLOBOTHALAMEA Pawlowski, Holzmann and Tyszka, 2013.

Subclass TEXTULARIANA Mikhalevich, 1980.

Order LITUOLIDA.

Suborder LITUOLINA Lankester, 1885.

Superfamily LITUOLOIDEA.

Family DISCAMMINIDAE Mikhalevich, 1980.

Genus Ammoscalaria Höglund, 1947.

Ammoscalaria sp., Pl. I, Figure 10.

Genus Discammina Lacroix, 1932.

Discammina sp., Pl. II, Figure 2.

Family HAPLOPHRAGMOIDIDAE Maync, 1952.

Genus Haplophragmoides Cushman, 1910.

1910 Haplophragmoides Cushman.

1960 Recurvoidella Uchio.

1973 Linguaferina Alekseychik-Mitskevich.

1973 Pauciloculina Alekseychik-Mitskevich.

1973 Subtilina Alekseychik-Mitskevich.

1981 Pseudohaploghragmoides Saidova.

1988 Haplophragmoides Loeblich and Tappan.

Haplophragmoides manilaensis Andersen, 1952, PI. II, Figure 7.

Haplophragmoides wilberti Andersen, 1953, PI. II, Figure 8.

1953 Haplophragmoides wilberti Andersen.

1994 Haplophragmoides wilberti (Andersen) Hayward and Hollis.

1999 Haplophragmoides wilberti (Andersen) Hayward, Grenfell, Reid and

Hayward.

2013 Haplophragmoides wilberti (Andersen) Debenay.

Haplophragmoides sp.

Genus Trochamminita Cushman and Brönnimann, 1948.

Trochamminita irregularis Cushman and Brönnimann, 1948, PI.

III, Figure 21.

1948 Trochamminita salsa Cushman and Brönnimann.

1957 Trochamminita salsa (Cushman and Brönnimann) Saunders.

Trochamminita salsa (Cushman and Brönnimann, 1948), PI. III,

Figure 22.

1948 Labrospira salsa Cushman and Brönnimann.

1948 Trochamminita irregularis Cushman and Brönnimann.

1957 Trochamminita salsa (Cushman and Brönnimann) Saunders.

1994 Trochamminita salsa (Cushman and Brönnimann) Hayward and Hollis.

1999 Trochamminita salsa (Cushman and Brönnimann) Hayward, Grenfell, Reid and Hayward. 
Family LITUOLIDAE Blainville, 1827.

Subfamily AMMOASTUTINAE Loeblich and Tappan, 1984.

Genus Ammoastuta Cushman and Brönnimann, 1948.

Ammoastuta inepta (Cushman and McCulloch, 1939), PI. I,

Figures $3 \mathrm{~A}$ and $\mathrm{B}$.

1939 Ammobaculites ineptus Cushman and McCulloch.

1948 Ammoastuta inepta (Cushman and McCulloch) Cushman and Brönnimann.

1962 Ammoastuta inepta (Cushman and McCulloch) Closs.

Ammoastuta salsa Cushman and Brönnimann, 1948, PI. I, Figure 4.

1948 Ammoastuta salsa Cushman and Brönnimann.

1952 Ammoastuta salsa (Cushman and Brönnimann) Bursch.

1986 Ammoastuta salsa (Cushman and Brönnimann) Brönnimann.

Subfamily AMMOMARGINULININAE Podobina, 1978.

Genus Ammobaculites Cushman, 1910.

Ammobaculites dilatatus Cushman and Brönnimann, 1948.

1948 Ammobaculites dilatatus Cushman and Brönnimann.

2002 Ammotium dilatatus (Cushman and Brönnimann) Debenay, Guiral and Parra.

Ammobaculites exiguus Cushman and Brönnimann, 1948, PI. I,

Figure 5.

1948 Ammobaculites exiguus Cushman and Brönnimann.

1992 Ammobaculites exiguus (Cushman and Brönnimann) Brönnimann, Whittaker and Zaninetti.

1994 Ammobaculites exiguus (Cushman and Brönnimann) Hayward and Hollis.

1999 Ammobaculites exiguus (Cushman and Brönnimann) Hayward,

Grenfell, Reid and Hayward.

2013 Ammobaculites exiguus (Cushman and Brönnimann) Debenay.

Genus Ammotium Loeblich and Tappan, 1953.

1953 Ammotium Loeblich and Tappan.

1960 Ammovaginulina Nakkady and Eissa.

1988 Ammotium Loeblich and Tappan.

Ammotium angulatum Brönnimann, Whittaker and Zaninetti, 1992.

Ammotium cassis (Parker, 1870), PI. I, Figure 11.

1870 Lituola cassis Parker.

1870 Ammobaculites cassis (Parker) Parker.

1870 Haplophragmium cassis (Parker) Parker.

1953 Ammotium cassis (Parker) Loeblich and Tappan.

1980 Ammotium cassis (Parker) Boltovskoy, Giussani, Watanabe and Wright.

Ammotium directum (Cushman and Brönniman, 1948), Pl. I,

Figure 12.

1948 Ammobaculites directus Cushman and Brönniman.

1948 Ammobaculites diversus Cushman and Brönniman.

1953 Ammotium directum Loeblich and Tappan.

Ammotium morenoi (Acosta, 1940), PI. I, Figure 13.

1940 Ammobaculites morenoi Acosta. 
1948 Ammobaculites salsus Cushman and Brönniman.

1948 Ammobaculites salsus var. distinctus Cushman and Brönniman.

1952 Ammoscalaria fluvialis Parker.

1957 Ammotium palustre Warren.

1992 Ammotium morenoi Brönnimann, Whittaker and Zaninetti.

Ammotium planissimum (Cushman, 1927).

1927 Haplophragmoides planissima Cushman.

1973 Ammotium planissimum Lankford and Phleger.

Ammotium pseudocassis (Cushman and Brönnimann, 1948), PI. I,

Figure 14

1948 Ammobaculites pseudocassis Cushman and Brönniman.

1953 Ammotium pseudocassis (Cushman and Brönniman) Loeblich and Tappan.

1992 Ammotium pseudocassis (Cushman and Brönniman) Brönnimann, Whittaker and Zaninetti.

Ammotium salsum (Cushman and Brönnimann, 1948) PI. I,

Figure 15.

1948 Ammobaculites salsus Cushman and Brönniman.

1953 Ammotium salsum (Cushman and Brönnimann) Loeblich and Tappan.

1967 Ammotium palustre Warren.

2013 Ammotium salsum (Cushman and Brönnimann) Boltovskoy, Giussani, Watanabe and Wright.

2013 Ammotium salsum (Cushman and Brönnimann) Debenay.

Subfamily LITUOLINAE Blainville, 1827.

Genus Lituola Lamarck, 1804.

1804 Lituola Lamarck.

1862 Lituola Reuss.

1918 Lituola (Lamarck) Cushman.

Lituola sp., Pl. II, Figure 14.

Superfamily LITUOTUBOIDEA.

Family LITUOTUBIDAE Loeblich and Tapan, 1984.

Genus Lituotuba Rhumbler, 1895.

1895 Lituotuba Rhumbler.

1913 Arlituotubum Rhumbler.

1981 Lituiforminoides Saidova.

1988 Lituotuba (Rhumbler) Loeblich and Tappan.

Lituotuba sp., PI. II, Figure 15.

Superfamily RECURVOIDOIDEA Alekseychik-Mitskevich, 1973.

Family ACUPEINIDAE Brönnimann and Zaninetti, 1984.

Genus Acupeina Brönniman and Zaninetti, 1984.

Acupeina triperforata (Millett, 1899), Pl. I, Figures $2 \mathrm{~A}$ and B. 1899 Haplophragmium agglutinans var. triperforata Millett. 1948 Haplophragmium salsum (Millett) Cushman and Bronnimann. 1984 Acupeina triperforata (Millett) Brönnimann and Zaninetti. 2002 Acupeina triperforata (Millett) Debenay, Guiral and Parra. 2013 Acupeina triperforata (Millett) Debenay. 
Suborder RZEHAKININA Saidova, 1981.

Superfamily RZEHAKINOIDEA Cushman, 1933.

Family TRILOCULARENIDAE Mikhalevich and Kaminski, 2008.

Genus Trilocularena Loeblich and Tappan, 1955.

Trilocularena patensis Closs, 1963, PI. III, Figure 18.

1963 Trilocularena patensis Closs.

2013 Trilocularena patensis (Closs) Debenay.

Suborder SPIROPLECTAMMININA Mikhalevich, 1992.

Superfamily SPIROPLECTAMMINOIDEA Cushman, 1927.

Family SPIROPLECTAMMINIDAE Cushman, 1927.

Subfamily SPIROPLECTAMMININAE Cushman, 1927.

Genus Ammobaculoides Plummer, 1932.

Ammobaculoides sp., Pl. I, Figure 6.

Genus Spiroplectammina Cushman, 1927.

Spiroplectammina biformis (Parker and Jones, 1865), PI. III, Figure 13.

1835 Textularia aglutinans var. biformis Parker and Jones.

1884 Spiroplecta biformis (Parker and Jones) Brady.

1932 Spiroplectammina biformis (Parker and Jones) Heron-Allen and

Earland.

1962 Spiroplectammina biformis (Parker and Jones) Closs.

2013 Spiroplectammina biformis (Parker and Jones) Debenay.

Family TEXTULARIOPSIDAE Loeblich and Tappan, 1982.

Genus Monotalea Brönnimann, Whittaker and Zaninetti, 1992.

Monotalea salsa Brönnimann, Whittaker and Zaninetti, 1992, PI.

II, Figure 18.

1992 Monotalea salsa Brönnimann, Whittaker and Zaninetti.

2013 Monotalea salsa (Brönnimann, Whittaker and Zaninetti) Debenay.

Suborder TROCHAMMININA Saidova, 1981.

Superfamily TROCHAMMINOIDEA Schwager, 1877.

Family REMANEICIDAE Loeblich and Tappan, 1964.

Subfamily ASTEROTROCHAMMININAE Brönnimann, Zaninetti and Whittaker, 1983.

Genus Asterotrochammina Bermúdez and Seiglie, 1963.

Asterotrochammina sp., PI. I, Figure 17.

Subfamily REMANEICINAE Loeblich and Tappan, 1964.

Genus Remaneica Rhumbler, 1938.

Remaneica sp., PI. III, Figures 9 A and B.

Family TROCHAMMINIDAE Schwager, 1877.

Subfamily ARENOPARELLINAE Saidova, 1981.

Genus Arenoparrella Andersen, 1951.

Arenoparrella mexicana (Kornfeld, 1931), Pl. I, Figures 16A and B.

1931 Trochammina inflata var. mexicana Kornfeld.

1951 Arenoparrella mexicana (Kornfeld) Andersen.

1992 Arenoparrella mexicana (Kornfeld) Brönnimann, Whittaker and

Zaninetti.

2007 Arenoparrella mexicana (Kornfeld) Berkeley, Perry, Smithers, Horton and Taylor.

2013 Arenoparrella mexicana (Kornfeld) Debenay. 
Subfamily JADAMMININAE Saidova, 1981.

Genus Entzia Daday, 1883.

1883 Entzia Daday.

1938 Jadammina Bartenstein and Brand.

2018 Entzia Hayward, Le Coze and Gross.

Entzia macrescens (Brady, 1870), PI. II, Figures $4 \mathrm{~A}$ and B.

1870 Trochammina inflata var. macrescens Brady.

1938 Jadammina macrescens (Brady) Bartenstein and Brand.

1980 Trochammina macrescens (Brady) Scott and Medioli.

1994 Jadammina macrescens (Brady) Hayward and Hollis.

1999 Jadammina macrescens (Brady) Hayward, Grenfell, Reid and

Hayward.

2005 Trochammina macrescens (Brady) Barbosa, Scott, Seoane and Turcq.

2013 Jadammina macrescens (Brady) Debenay.

2018 Entzia macrescens (Brady) Hayward, Le Coze and Gross.

Entzia polystoma (Bartenstein and Brand, 1938).

1938 Jadammina polystoma Bartenstein and Brand.

2018 Entzia polystoma Hayward, Le Coze and Gross.

Entzia sp.

Subfamily POLYSTOMAMMININAE Brönnimann and Beurlen, 1977.

Genus Deuterammina Brönnimann, 1976.

1976 Deuterammina Brönnimann.

1983 Deuterammina (Centrodeuterammina) (Brönnimann) Brönnimann and Whittaker.

1988 Deuterammina (Brönnimann) Loeblich and Tappan.

Deuterammina sp., PI. II, Figures $1 \mathrm{~A}$ and $\mathrm{B}$.

Genus Lepidodeuterammina Brönnimann and Whittaker, 1983.

1983 Deuterammina (Ledpdodeuterammina) Brönnimann and Whittaker.

1988 Lepidodeuterammina (Brönnimann and Whittaker) Loeblich and Tappan.

Lepidodeuterammina ochracea (Williamson, 1858), PI. II, Figures $13 \mathrm{~A}$ and $\mathrm{B}$. 1858 Rotalina ochracea Williamson.

1983 Deuterammina (Lepideuterammina) ochracea Brönnimann and Whittaker.

1980 Trochammina ochracea (Wiliamson) Boltovskoy, Giussani, Watanabe and Wright.

2018 Lepideuterammina ochracea Hayward, Le Coze and Gross.

Subfamily ROTALIAMMININAE Saidova, 1981.

Genus Rotaliammina Cushman, 1924.

1924 Rotaliammina Cushman.

1964 Polysiphotrocha Seiglie.

1988 Rotaliammina (Cushman) Loeblich and Tappan.

Rotaliammina sp., PI. III, Figures $11 \mathrm{~A}, \mathrm{~B}$ and C.

Genus Siphotrochammina Saunders, 1957.

Siphotrochammina lobata Saunders, 1957, PI. III, Figures 12A and B.

1957 Siphotrochammina lobata Saunders.

1977 Siphotrochammina elegans Zaninetti, Brönnimann, Beurlen and Moura.

2013 Siphotrochammina lobata (Saunders) Debenay.

Siphotrochammina sp. 
Genus Tiphotrocha Saunders, 1957.

Tiphotrocha comprimata (Cushman and Brönnimann, 1948), PI. III, Figures $17 \mathrm{~A}$ and $\mathrm{B}$.

1948 Trochammina comprimata Cushman and Brönnimann.

1957 Tiphotrocha comprimata (Cushman and Brönnimann) Saunders.

1980 Tiphotrocha comprimata (Cushman and Brönnimann) Scott and Medioli.

1992 Tiphotrocha comprimata (Cushman and Brönnimann) Brönnimann, Whittaker and Zaninetti.

2006 Tiphotrocha comprimata (Cushman and Brönnimann) Horton and Edwards.

Subfamily TROCHAMMININAE Schwager, 1877.

Genus Paratrochammina Brönnimann, 1979.

Paratrochammina clossi Brönnimann, 1979, PI. II, Figures 19A and B.

Paratrochammina sp.

Genus Portatrochammina Echols, 1971.

1971 Portatrochammina Echols.

1983 Portatrochammina (Paratrochammina) (Echols) Brönnimann, Zaninetti and Whitakker.

1971 Portatrochammina (Echols) Loeblich and Tappan.

Portatrochammina sp., PI. III, Figures $2 \mathrm{~A}$ and B.

Genus Trochammina (Parker and Jones, 1859).

1859 Rotalia (Trochammina) Parker and Jones.

1860 Trochammina (Parker and Jones) Jones and Parker.

1988 Trochammina (Parker and Jones) Loeblich and Tappan.

Trochammina inflata (Montagu, 1808), PI. III, Figures 19A and B.

1808 Nautilus inflatus Montagu.

1859 Trochammina inflata (Montagu) Parker and Jones.

1994 Trochammina inflata (Montagu) Hayward and Hollis.

1999 Trochammina inflata (Montagu) Hayward, Grenfell, Reid and Hayward.

2006 Trochammina inflata (Montagu) Horton and Edwards.

2013 Trochammina inflata (Montagu) Debenay.

Trochammina squamata Jones and Parker, 1860, PI. III, Figure 20.

1860 Trochammina squamata Jones and Parker.

1964 Trochammina squamata (Jones and Parker) Hedley, Hurdle and Burdett.

1980 Trochammina squamata (Jones and Parker) Boltovskoy, Giussani, Watanabe and Wright.

Trochammina sp.

Suborder VERNEUILININA Mikhalevich and Kaminski, 2000.

Superfamily VERNEUILINOIDEA Cushman, 1911.

Family REOPHACELLIDAE Mikhalevich and Kaminski, 2000.

Subfamily CARONIINAE Brönnimann, Whittaker and Zaninetti, 1992.

Genus Caronia Brönnimann, Whittaker and Zaninetti, 1992.

Caronia exilis (Brönnimann and Cushman, 1948), PI. I, Figure 24.

1948 Gaudryina exilis Brönnimann and Cushmann. 
1992 Caronia exilis (Brönnimann and Cushmann) Brönnimann, Whittaker and Zaninetti.

2002 Caronia exilis (Brönnimann and Cushmann) Debenay, Guiral and Parra.

2013 Caronia exilis (Brönnimann and Cushmann) Debenay.

Order TEXTULARIIDA.

Suborder TEXTULARIINA Delage and Hérouard, 1896.

Superfamily EGGERELLOIDEA Cushman, 1937.

Family PSEUDOGAUDRYINIDAE Loeblich and Tappan, 1985.

Subfamily PSEUDOGAUDRYININAE Loeblich and Tappan, 1985.

Genus Pseudoclavulina Cushman, 1936.

Pseudoclavulina curta Cushman and Brönnimann, 1948, PI. III, Figure 6.

Pseudoclavulina gracilis Zheng, 1988, PI. III, Figures 7 A and B.

Pseudoclavulina sp.

Family VALVULAMMINIDAE Loeblich and Tappan, 1986.

Genus Discorinopsis Cole, 1941.

Discorinospsis aguayoi (Bermúdez, 1935), PI. II, Figures 3 A and B.

1935 Discorbis aguayoi Bermúdez.

1941 Discorinopsis aguayoi Cole.

Superfamily TEXTULARIOIDEA Ehrenberg, 1838.

Family TEXTULARIIDAE Ehrenberg, 1838.

Subfamily TEXTULARIINAE Ehrenberg, 1838.

Genus Bigenerina d'Ornigny, 1826.

Bigenerina sp., Pl. I, Figure 21.

Genus Textularia Defrance, 1824.

Textularia earlandi Parker, 1952, PI. III, Figure 14.

1952 Textularia earlandi Parker.

1994 Textularia earlandi (Parker) Hayward and Hollis.

1999 Textularia earlandi (Parker) Hayward, Grenfell, Reid and Hayward.

2010 Textularia earlandi (Parker) Alve and Goldstein.

Class MONOTHALAMEA.

Textularia gramen d'Orbigny 1846, PI. III, Figure 15.

Order ASTRORHIZIDA.

Suborder SACCAMMININA.

Superfamily PSAMMOSPHAEROIDEA.

Family POLYSACCAMMINIDAE.

Subfamily POLYSACCAMININAE.

Genus Polysaccammina Scott, 1976.

Polysaccammina hyperhalina Medioli, Scott and Petrucci, 1983, PI. II, Figure 20.

Polysaccamina ipohalina Scott, 1976, PI. III, Figure 1.

1976 Polysaccamina ipohalina Scott.

1980 Polysaccamina ipohalina (Scott) Scott and Medioli.

Class NODOSARIATA Mikhalevich, 1992 emend. Rigaud, Vachard, Schlagintweit, Martini and 2015.

Subclass HORMOSINANA Mikhalevich, 1992.

Superfamily CRIBRATINOIDEA Loeblich and Tappan, 1984.

Family THOMASINELLIDAE Loeblich and Tappan, $1984 \dagger$.

Genus Protoschista Eimer and Fickert, 1899. 
Protoschista findens (Parker, 1870), PI. III, Figures $3 \mathrm{~A}$ and B.

1870 Lituola findens Parker.

1953 Protoschista findens (Parker) Loeblich and Tappan.

Suborder HORMOSININA.

Superfamily HORMOSINOIDEA.

Family HORMOSINIDAE.

Subfamily CUNEATINAE.

Genus Acostata (Acosta, 1940).

1940 Reophax Acosta.

1992 Acostata Brönnimann, Whitaker and Valleri, 1992.

Acostata mariae (Acosta, 1940), Pl. I, Figure 1.

1940 Reophax mariae Acosta.

1980 "Hormosina" mariae (Acosta) Brönnimann.

1992 Acostata mariae (Acosta) Brönnimann, Whitaker and Valleri.

Genus Warrenita Loeblich and Tappan, 1984.

Warrenita palustris (Warren, 1957), PI. III, Figure 23.

1957 Sulcophax palustris Warren.

1984 Warrenita palustris Loeblich and Tappan.

Family REOPHACIDAE Cushman, 1927.

Genus Reophax Monfort, 1808.

Reophax nana Rhumbler, 1913, PI. III, Figure 10.

1913 Reophax nana Rhumbler.

2005 Reophax nana (Rhumbler) Barbosa, Scott, Seoane and Turcq.

2013 Reophax nana (Rhumbler) Debenay.

Reophax sp.

Class TUBOTHALAMEA Pawlowski, Holzman and Tyszka, 2013.

Order MILIOLIDA Delage and Hérouard, 1896.

Family MILIAMMINIDAE Saidova, 1981.

Genus Miliammina Heron-Allen and Earland, 1930.

Miliammina earlandi Loeblich and Tappan, 1955, PI. II, Figure 16.

Miliammina fusca (Brady, 1870), PI. II, Figures 17A and B.

1870 Quinqueloculina fusca Brady.

1930 Miliammina fusca (Brady) Heron-Allen and Earland.

1936 Miliammina fusca (Brady) Rhumbler.

1953 Miliammina fusca (Brady) Miller.

1992 Miliammina fusca (Brady) Brönnimann, Whittaker and Zaninetti.

1994 Miliammina fusca (Brady) Hayward and Hollis.

1999 Miliammina fusca (Brady) Debenay, Grenfell, Reid and Hayward.

2013 Miliammina fusca (Brady) Debenay.

Miliammina sp.

Order SPIRILLINIDA Hohenegger and Piller, 1975.

Suborder AMMODISCINA Mikhalevich, 1980.

Superfamily AMMODISCOIDEA Reuss, 1862.

Family AMMODISCIDAE Reuss, 1862.

Subfamily AMMODISCINAE Reuss, 1862.

Genus Ammodiscus Reuss, 1862.

Ammodiscus sp., PI. I, Figure 8.

Genus Ammodiscoides Cushman, 1909. 
Ammodiscoides turbinatus Cushman, 1909, PI. I, Figure 7.

Subfamily USBEKISTANIINAE Vyalov, 1968.

Genus Glomospira Rzehak, 1885.

"Glomospira" glomerata (Grzybowsky, 1898), PI. Il, Figure 5.

1898 Ammodiscus glomeratus Grzybowsky.

2005 "Glomospira" glomerata Kaminski and Gradstein.

Glomospira gordialis (Jones and Parker, 1860), PI. II, Figure 6.

1860 Trochammina squamata var. gordialis Jones and Parker.

1885 Glomospira gordialis (Jones and Parker) Rzehak.

1994 "Glomospira gordialis" (Jones and Parker) Hayward and Hollis.

2013 Glomospira gordialis (Jones and Parker) Debenay.

Glomospira sp.

\section{CONCLUSION}

Considering the territorial dimensions of the Brazilian mangroves, the high concentration of results in the states of Sao Paulo and Rio de Janeiro (Table 1), the very limited number of mangroves analyzed on the Northeastern and Northern Brazilian coast, as well as the results from several works that have never been published, the number of species is potentially higher than now recorded. Moreover, new tools for environmental genetic analysis have contributed to revealing a significant abundance of cryptic species present in the environment, which may be taken into account.

In this case, monothalamous species are a particular group rarely reported in the literature. Although in estuarine environments such species are indeed rare in abundance, their occurrence may be underestimated because not all researchers recognize the tests of these species as foraminifera. It can be inferred from the fact that certain species are reported only by a researcher or research group who, having found them at some time, tends to report them again in other works. Besides, it should be considered that some sample preparation procedures potentially eliminate species that attach to substrates, such as sieving (excluding large fragments or particles where individuals may be attached) and flotation (decantation of denser particles with attached tests).

In addition to these factors, 28 genera were reported at some point without species identification (Table 1): Ammobaculites sp., Ammobaculoides sp., Ammodiscus sp., Ammopemphix sp., Ammoscalaria sp., Ammotium sp., Asterotrochammina sp., Bigenerina sp., Chitinosaccus sp., Crithionina sp., Deuterammina sp., Discammina sp., Entzia sp., Glomospira sp., Haplophragmoides sp., Iridia sp., Lituola sp., Lituotuba sp., Miliammina sp., Paratrochammina sp., Portatrochammina sp., Pseudoclavulina sp., Remaneica sp., Reophax sp., Rotaliammina sp., Siphotrochammina sp., Textularia sp. and Trochammina sp. In some cases, the conditions of the tests probably have not facilitated species identification, although it was possible to recognize the genus. However, in the cases of the genera Ammobaculoides, Ammodiscus, Ammopemphix, Ammoscalaria, Asterotrochammina, Bigenerina, Deuterammina, Discammina, Lituotuba, Portatrochammina, Remaneica and Rotaliammina, no species have ever been identified in the Brazilian mangroves.

In addition to the possibility that these genera include species not yet described in the literature, it may emphasize the potential impact that species omission can have on ecological indices (e.g., diversity and evenness), as well as for comparison between assemblages (similarity indices), which are strongly influenced by taxonomic accuracy. Additionally, the synonyms may draw attention, since some same genera and species are reported differently in the literature. It is the case, for example, of the genus Entzia, the accepted synonym for the genus Jadammina, which in its turn has moved to the status of "not accepted" on the platform maintained by Hayward et al. (2019).

Among the 91 species reported in Brazil, 56 of them were illustrated by SEM images (Table 1). The absence of several species is because they are 
Table 1. List of agglutinant and monothalamous foraminifera species reported from Brazilian mangroves with the geographical regions and references, respectively Symbol " $\mathrm{X}$ " indicates the presence of the species.

\begin{tabular}{|c|c|c|c|c|c|c|c|c|c|c|c|c|c|c|}
\hline Locality & 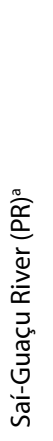 & 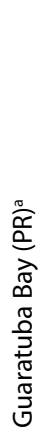 & 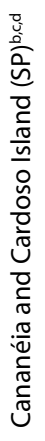 & 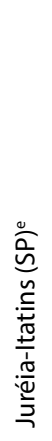 & 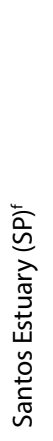 & 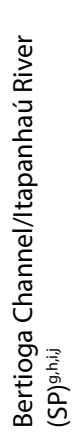 & 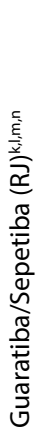 & 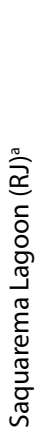 & 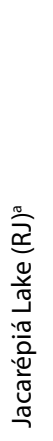 & 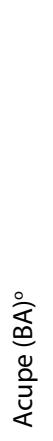 & 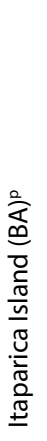 & 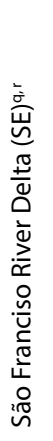 & 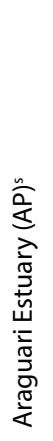 & 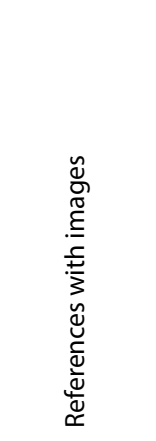 \\
\hline Acostata mariae & . & . & $x$ & . & . & . & . & . & . & . & . & . & . & . \\
\hline Acupeina triperforata & . & . & $x$ & . & . & . & $x$ & . & . & . & . & . & . & $c, n$ \\
\hline Ammoastuta inepta & $x$ & $x$ & . & . & . & $x$ & $x$ & . & . & $x$ & . & $x$ & . & $a, q, n$ \\
\hline Ammoastuta salsa & . & . & $\mathrm{x}$ & . & $\mathrm{X}$ & $x$ & $x$ & . & . & $x$ & . & & . & $c, i, k, n$ \\
\hline Ammobaculites exiguus & . & $x$ & $x$ & . & . & $x$ & $x$ & . & . & $x$ & . & $x$ & . & $a, c, q, n$ \\
\hline Ammobaculites sp. & . & . & $x$ & . & $x$ & $x$ & $\mathrm{x}$ & . & . & $x$ & . & . & . & c \\
\hline Ammobaculoides sp. & . & . & $x$ & . & . & . & . & . & . & . & . & . & . & . \\
\hline Ammodiscoides turbinatus & . & $x$ & . & . & . & . & . & . & . & . & . & . & . & . \\
\hline Ammodiscus sp. & . & $x$ & . & . & . & $x$ & $x$ & . & . & $x$ & . & $x$ & . & $a, q, n$ \\
\hline Ammopemphix sp. & . & . & . & . & . & . & $x$ & . & $x$ & . & . & . & . & $\mathrm{a}, \mathrm{n}$ \\
\hline Ammoscalaria sp. & . & . & $x$ & . & . & . & . & . & . & . & . & . & . & . \\
\hline Ammotium angulatum & . & . & . & . & . & $x$ & . & . & . & . & . & . & . & . \\
\hline Ammotium cassis & . & . & $x$ & . & $x$ & $x$ & $x$ & . & . & . & . & $x$ & . & $c, q, n$ \\
\hline Ammotium directum & . & $x$ & $x$ & . & . & $x$ & $x$ & . & . & $x$ & $x$ & . & . & $a, d, n, p$ \\
\hline Ammotium morenoi & . & . & $x$ & . & . & $\mathrm{x}$ & . & . & . & . & . & . & . & . \\
\hline Ammotium pseudocassis & . & . & $x$ & . & . & $x$ & $x$ & . & . & $x$ & . & $x$ & . & $q$ \\
\hline Ammotium salsum & $x$ & $\mathrm{x}$ & $x$ & . & . & $x$ & $x$ & . & . & $x$ & $x$ & $x$ & . & $\begin{array}{c}a, c, e, i, k, n, \\
p, q\end{array}$ \\
\hline Ammotium sp. & . & . & . & . & $x$ & . & . & . & . & $x$ & . & . & . & $\cdot$ \\
\hline Arenoparrella mexicana & $x$ & $x$ & $x$ & $x$ & $x$ & $x$ & $x$ & . & . & $x$ & . & $x$ & $x$ & $\begin{array}{c}a, c, d, e, i, k \\
n, q\end{array}$ \\
\hline Asterotrochammina sp. & . & . & . & $x$ & . & . & . & . & . & . & . & . & . & . \\
\hline Astrammina rara & . & . & . & . & . & . & $x$ & . & . & . & . & . & . & $\mathrm{k}, \mathrm{n}$ \\
\hline Bahianofusus pontei & . & . & . & . & . & . & $x$ & . & . & . & . & . & . & $\mathrm{l}, \mathrm{n}$ \\
\hline Bahianotubus salvadorensis & . & . & . & . & . & . & $x$ & . & . & . & . & . & . & $\mathrm{l}, \mathrm{n}$ \\
\hline Bigenerina sp. & . & $x$ & $x$ & . & . & . & . & . & . & . & . & . & . & $a, c$ \\
\hline Blysmasphaera brasiliensis & . & . & $x$ & . & . & . & . & . & . & . & . & . & . & $q, n, r$ \\
\hline $\begin{array}{l}\text { Blysmasphaera broenni- } \\
\text { manni }\end{array}$ & . & . & . & . & . & . & $\cdot$ & $\cdot$ & $\cdot$ & . & $\cdot$ & $x$ & . & $\mathrm{r}$ \\
\hline Caronia exilis & . & $x$ & $\mathrm{x}$ & $x$ & . & $x$ & $x$ & . & . & $x$ & . & . & . & $a, c, e, n, k$ \\
\hline Chitinosaccus guaratibaensis & . & . & . & . & . & . & $x$ & . & . & . & . & . & . & $\mathrm{l}, \mathrm{n}$ \\
\hline Chitinosaccus sp. & . & $x$ & $x$ & . & . & . & . & . & . & . & . & . & . & c \\
\hline Chitinosaccus zuluensis & . & . & . & . & . & . & $x$ & . & . & . & . & . & . & $\mathrm{k}$ \\
\hline Crithionina mamilla & . & . & . & . & . & . & $x$ & . & . & . & . & . & . & . \\
\hline Crithionina sp. & . & . & . & . & . & . & . & . & . & $x$ & . & . & . & . \\
\hline
\end{tabular}


Continued Table 1.

Discammina sp.

Discorinopsis aguayoi

Entzia macrescens

Entzia polystoma

Entzia sp.

"Glomospira" glomerata

Glomospira gordialis

Glomospira sp.

Haplophragmoides

manilaensis

$x \quad x \quad x$

Haplophragmoides sp.

Haplophragmoides wilberti

Hemisphaerammina bradyi

Iridia diaphana

Iridia sp.

Lepidodeuterammina

ochracea

Lituola sp.

Lituotuba sp.

Miliammina earlandi

Miliammina fusca

Miliammina pariaensis

Miliammina sp.

Monotalea salsa

Pararotalia cananeiaensis

Paratrochammina clossi

Paratrochammina sp.

Polysaccammina hyperhalina

Polysaccammina ipohalina

Portatrochammina sp.

Protoschista findes

Psammosphaera frankei

Psammosphaera fuscaf.

adhaerens

Pseudoclavulina curta

Pseudoclavulina gracilis

Pseudoclavulina sp.

Pseudothurammina limnetis

Remaneica sp.

Reophax nana

Reophax palustris

Reophax sp.

Rotaliammina sp.

Siphotrochammina elegans

X $\quad \mathrm{x}$

a, $\mathrm{n}$

c

$\mathrm{X}$

- $x$

c

$\mathrm{a}, \mathrm{q}, \mathrm{n}$

$\mathrm{p}$ $\mathrm{a}, \mathrm{n}$

$\mathrm{n}$

c

$\begin{array}{lllllll} & x & x & x & \end{array}$

$\mathrm{X}$

$X$

$x$

q

n

C

a, q

a, c, k

a

k

a, c

a

a, c 


\section{Continued Table 1.}

\begin{tabular}{|c|c|c|c|c|c|c|c|c|c|c|c|c|c|c|}
\hline Siphotrochammina lobata & . & . & $x$ & $x$ & $x$ & $x$ & $x$ & . & . & $\mathrm{x}$ & . & . & $\mathrm{x}$ & $c, i, n$ \\
\hline Siphotrochammina sp. & . & $\mathrm{X}$ & . & . & . & . & . & . & . & . & . & . & . & . \\
\hline Spiroplectammina biformis & . & $x$ & . & . & . & . & . & . & . & . & . & . & . & . \\
\hline Textularia earlandi & $x$ & $\mathrm{X}$ & $x$ & . & . & $x$ & $\mathrm{X}$ & . & . & . & $x$ & $x$ & . & $\mathrm{d}, \mathrm{n}, \mathrm{q}$ \\
\hline Textularia gramen & . & . & . & . & . & . & . & . & . & . & $x$ & . & . & $\mathrm{p}$ \\
\hline Textularia paranaguensis & . & . & . & . & . & . & $x$ & . & . & . & . & . & . & $\mathrm{n}$ \\
\hline Textularia sp. & . & . & $x$ & . & . & . & . & . & . & . & . & . & . & . \\
\hline Tholosina centroforata & . & . & . & . & . & . & . & . & $\mathrm{x}$ & . & . & . & . & . \\
\hline Tiphotrocha comprimata & $x$ & $x$ & $x$ & . & . & $x$ & $\mathrm{X}$ & . & . & $\mathrm{x}$ & $x$ & . & . & $a, c, n, k$ \\
\hline Trilocularena patensis & . & . & . & . & . & . & $x$ & . & . & . & . & . & . & . \\
\hline Trochammina inflata & $x$ & $x$ & $x$ & . & $x$ & $x$ & $x$ & . & . & $x$ & $\mathrm{x}$ & . & . & $a, c, d, i, k, n, p$ \\
\hline Trochammina sp. & . & $x$ & $x$ & . & . & $x$ & . & $x$ & $x$ & $\mathrm{x}$ & . & . & . & c \\
\hline Trochammina squamata & $x$ & $x$ & $x$ & . & . & . & $x$ & . & . & . & . & . & $\mathrm{x}$ & $\mathrm{a}, \mathrm{n}$ \\
\hline Trochamminita irregularis & . & . & $x$ & . & . & . & $\mathrm{X}$ & . & . & . & . & $\mathrm{x}$ & . & $c, k, q, n$ \\
\hline Trochamminita salsa & . & . & . & . & . & $x$ & $x$ & . & . & $\mathrm{x}$ & . & . & $x$ & . \\
\hline Warrenita palustris & . & . & $\mathrm{X}$ & . & . & $x$ & $\mathrm{X}$ & . & . & & . & $X$ & . & $c, q, n$ \\
\hline
\end{tabular}

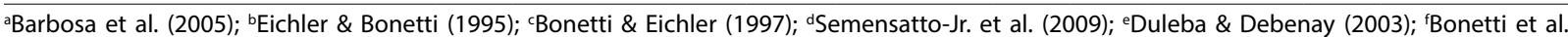
(2002); ' ${ }^{2}$ Eichler et al. (2007); ' Passos et al. (2017); 'Eichler (2019); 'Kukimodo \& Semensatto (2019); 'Zaninetti et al. (1977); 'Brönnimann et al. (1979); mBrönnimann et al. (1981); 'Laut \& Rodrigues (2011); 'Zaninetti et al. (1979); ' Zerfass et al. (2006); ' ${ }^{\circ}$ Semensatto Jr. \& Dias-Brito (2004); 'Semensatto et al. (2008); 'saut et al. (2010).

generally rare, and their tests may not have adequate conditions for image capture, and in the publications, it is preferred to illustrate the main species found. Thus, it is suggested to publish images of species not yet illustrated in Brazil, in order to constitute visual references and contribute to their identification.

\section{ACKNOWLEDGEMENTS}

The author is grateful to Prof. Dr. Francisco Fatela and Dr. João Moreno (Universidade de Lisboa, Portugal), Prof. Dr. Lázaro Laut (Universidade Federal do Estado do Rio de Janeiro), Prof. Dr. Sibelle Trevisan Disaró (Universidade Federal do Paraná), Dr. Natália Rudorff (Instituto Nacional de Pesquisas Espaciais), MSc. Joana Santa-Cruz (Fundação de Amparo à Pesquisa no Estado de São Paulo), Dr. Sarita Camacho (Universidade do Algarve) and editors of journals that authorized reuse of images of foraminifera, and to Prof. Dr. Dimas Dias-Brito (Universidade Estadual Paulista, Brazil) for advising and supporting the acquiring of some foraminifera images (SEM) that form part of the author's collection here illustrated. Part of foraminifera images acquired (SEM) was supported by scholarships granted from Fundação de Amparo à Pesquisa do Estado de São Paulo/FAPESP (Processes 01/11786-8 and 11/1687-4), Agência Nacional do Petróleo, Gás e Biocombustíveis (ANP/PRH-05), and Coordenação de
Aperfeiçoamento de Pessoal de Nível Superior/CAPES. Some foraminifera images (SEM) were acquired at UNESPetro (Centro de Geociências Aplicadas ao Petróleo, Universidade Estadual Paulista, Brazil) with the assistance of MSc. Hermes Dias Brito.

\section{REFERENCES}

ALVE, E., HESS, S., BOUCHET, V. M. P., DOLVEN, J. K. \& RYGG, B. 2019. Intercalibration of benthic foraminiferal and macrofaunal biotic indices: an example from the Norwegian Skagerrak coast (NE North Sea). Ecological Indicators, 96, 107-115.

ALVE, E., LEPLAND, A., MAGNUSSON, J. \& BACKER-OWE, K. 2009. Monitoring strategies for re-establishment of ecological reference conditions: possibilities and limitations. Marine Pollution Bulletin, 59, 8-12, 297-310.

BARBOSA, C. F., SCOTT, D. B., SEOANE, J. C. S. \& TURCQ, B. J. 2005. Foraminiferal zonations as base lines for quaternary sea-level fluctuations in south-southeast Brazilian mangroves and marshes. Journal of Foraminiferal Research, 35, 1, 22-43.

BOLTOVSKOY, E., GIUSSANI, G., WATANABE, S. \& WRIGHT, R. C. 1980. Atlas of benthic shelf foraminifera of the Southwest Atlantic, Hague Publishers, Boston, MA.

BONETTI, C. \& EICHLER, B. B. 1997. Benthic foraminifera and thecamoebians as indicators of river/sea gradients in the estuarine zone of Itapitangui River - Cananéia/SP, Brazil. Anais da Academia Brasileira de Ciências, 69, 4, 545-563.

BONETTI, C. H. C., EICHLER, B. B. \& DEBENAY, J. P. 2002. Evolução temporal da impactação do Sistema Estuarino de Santos - São Vicente (SP, Brasil) analisada através das populações de foraminíferos sub-recentes. Pesquisas em Geociências, 28, 2, 273-283. 
BORTOLUS, A. 2008. Error cascades in the biological sciences: the unwanted consequences of using bad taxonomy in ecology. Ambio, 37, 2, 114-118.

BOUCHET, V. M. P., ALVE, E., RYGG, B. \& TELFORD, R. J. 2012. Benthic foraminifera provide a promising tool for ecological quality assessment of marine waters. Ecological Indicators, 23, 66-75.

BRÖNNIMANN, P. 1979. Recent benthonic foraminifera from Brazil. Morphology and ecology. Part IV: Trochamminids from the Campos Shelf with description of Paratrochammina n. gen. Paläontologische Zeitschrift, 53, 1-2, 5-25.

BRÖNNIMANN P., DIAS-BRITO D. \& MOURA J.A. 1981. Foraminíferos da Fácies Mangue da planície de maré de Guaratiba, Rio de Janeiro, Brasil. Anais do II Congresso Latino-Americano de Paleontologia, 2, 877-891.

BRÖNNIMANN, P. \& DIAS-BRITO, D. 1982. New Litoulacea (Protista, Foraminiferida) from shallow waters of the Brazilian shelf. Journal of Foraminiferal Research, 12, 1, 13-23.

BRÖNNIMANN, P. WHITTAKER, J. E. \& ZANINETTI, L. 1992. Brackish water foraminifera from mangrove sediments of southwestern Viti Levu, Fiji Islands, Southwest Pacific. Revue de Paléobiologie, 11, 2, 13-65.

CAMACHO, S. G., MOURA, D. J. M., CONNOR, S., SCOTT, D. B. \& BOSKI, T. 2015. Taxonomy, ecology and biogeographical trends of dominant benthic foraminifera species from an Atlantic - Mediterranean estuary (the Guadiana, southeast Portugal). Palaeontologia Electronica, 18, 1-37.

CLARK, F. E. \& PATTERSON, T. 1993. An illustrated key to the identification of unilocular genera of calcareous foraminifera. Journal of Paleontology, 67, 1, 20-28.

CLOSS, D. 1962. Foraminíferos e tecamebas da Lagoa dos Patos (RS). Boletim da Escola de Geologia de Porto Alegre, 11, 1-130.

CUSHMAN, J. A. \& TODD, R. 1948. A foraminiferal fauna from the Cook Mountain Formation of Missisippi. Contributions from the Cushman Laboratory for Foraminiferal Research, 24, 2, 27-48

DEBENAY, J. P. 2013. A guide to 1,000 foraminifera from southwestern Pacific New Caledonia, Muséum National d'Histoire Naturelle, Paris, France.

DISARÓ, S. T. 2006. Foraminíferos em ecossistemas de manguezal e marismas salgadas. In: MONTEIRO-FILHO, E. L. A. \& ARANHA, J. M. R. (ed.), Revisões em Zoologia - I: Volume comemorativo dos 30 anos do Curso de Pós-Graduação em Zoologia da Universidade Federal do Paraná, Secretaria do Meio Ambiente do Estado do Paraná, Curitiba, PR, pp. 67-85.

DULEBA, W. \& DEBENAY, J. P. 2003. Hydrodynamic circulation in the estuaries of Estação Ecológica Juréia-Itatins, Brazil, inferred from foraminifera and thecamoebian assemblages. Journal of Foraminiferal Research, 33, 1, 62-93.

EICHLER, B. B. \& BONETTI, C. 1995. Distribuição dos foraminíferos e tecamebas ocorrentes no manguezal do Rio Baguaçu, Cananéia, São Paulo - relações com parâmetros ambientais. Pesquisas em Geociências, 22, 1-2, 32-37.

EICHLER, P. B. 2019. Foraminiferal zonation from a subtropical mangrove in Bertioga Channel (São Paulo, SP, Brazil). Regional Studies in Marine Science, 25, 100460.

EICHLER, P. B., EICHLER, B. B., MIRANDA, L. B. \& RODRIGUES, A. R. 2007. Modern foraminiferal facies in a subtropical estuarine channel, Bertioga, São Paulo, Brazil. Journal of Foraminiferal Research, 37, 3, 234-247.
ELLIS, B. F. \& MESSINA, A. R. 1940. et seq. Catalogue of foraminifera, Micropaleontology Press, New York, NY.

ENCARNAÇÃO, D. S. G. C. 2012. Ecologic zonation modelo f the benthic foraminifera and thecamoebians of Guadiana River estuary and application in paleoenvironmental reconstruction, PhD thesis, Algarve University, Faro, Portugal, viewed 20 March 2020, <http://hdl.handle.net/10400.1/7738>.

FRONTALINI, F., BUOSI, C., DA PELO, S., COCCIONI, R., CHERCHI, A. \& $\mathrm{BUCCl}, \mathrm{C} .2009$. Benthic foraminifera as bio-indicators of trace element pollution in the heavily contaminated Santa Gilla lagoon (Cagliari, Italy). Marine Pollution Bulletin, 58, 858-877.

GALEOTTI, S., KAMINSKI, M. A., COCCIONI, R. \& SPEIJER, R. P. 2004. High resolution deep-water agglutinated foraminiferal record across the Paleocene/Eocene transition in the Contessa Road Section (central Italy). Grzybowski Foundation Special Publication, 8, 83-103.

HAYWARD, B. W. \& HOLLIS, C. J. 1994. Brackish foraminifera in New Zealand: a taxonomic and ecologic review. Micropalentology, 40, 3, 185-222.

HAYWARD, B. W., GRENFELL, H. R., REID, C. M. \& HAYWARD, K. A. 1999. Recent New Zealand shallow-water benthic foraminifera: taxonomy, ecologic distribution, biogeography, and use in paleoenvironmental assessments, Institute of Geological \& Nuclear Sciences, Lower Hutt, New Zealand.

HAYWARD, B.W., LE COZE, F., VACHARD, D. \& GROSS, O. 2019. The World Foraminifera Database, Flanders Marine Institute, Ostend, Belgium, viewed 04 October 2019, <http://www. marinespecies.org/foraminifera>.

JONES, R. W. 1994. The challenger foraminifera. Oxford University Press, Oxford.

KAMINSKI, M. A., CETEAN, C. G. \& HENDERSON, A. S. 2008. Lectotypes of type species of Agglutinated Foraminiferal Genera in the Collections of the Natural History Museum, London. Part 1. Astrorhizina and Saccamminina. Grzybowski Foundation Special Publication, 13, 63-77.

KUKIMODO, I. \& SEMENSATTO, D. 2019. Sampling strategy always matters: methodological issues on collecting samples in tropical transitional environments for ecological analysis based on recent foraminifera. Marine Micropaleontology, 148, 46-57.

LAUT, L., CLEMENTE, I., MARTINS, M. V. A., FRONTALINI, F., RAPOSO, D., BELART, P., HABIB, R., FORTES, R. \& LORINI, M. L. 2017. Benthic Foraminifera and Thecamoebians of Godineau River Estuary, Gulf of Paria, Trinidad Island. Anuário do Instituto de Geociências - Universidade Federal do Rio de Janeiro, 40, 2, 118-143.

LAUT, L. L. M., SILVA, F. S., BONETTI, C., FIGUEIREDO, A. G. JR. \& CRAPEZ, M. A. C. 2007. Foraminíferos e atividade bacteriana aplicados no diagnóstico ambiental do rio Itacorubí, Florianópolis, SC. Revista Brasileira de Geociências, 37, 3, 565-578.

LAUT, L. L. M., FERREIRA, D. E. S., SANTOS, V. F., FIGUEIREDO, A. G. JR., CARVALHO, M. A. \& MACHADO, O. F. 2010. Foraminifera, thecamoebians and palynomorphs as hydrodynamic indicators in Araguari Estuary, Amazonian Coast, Amapá State - Brazil. Anuário do Instituto de Geociências - Universidade Federal do Rio de Janeiro, 33, 2, 52-65.

LAUT, L. L. M. \& RODRIGUES, M. A. C. 2011. Foraminíferos do manguezal de Guaratiba, Rio de Janeiro: revisão taxonômica e aplicação de análises multivariadas. In: CARVALHO, I., SRIVASTAVA, N. K., STROHSCHOEN, O. JR. \& LANA, C. C. (ed.), Paleontologia: Cenários da Vida. Interciência, Rio de Janeiro, RJ, v. 3, pp. 231-240. 
LAUT, L. L. M., SILVA, F. S., MARTINS, M. V. A., RODRIGUES, M. A. C., MENDONÇA, J. O., CLEMENTE, I. M. M. M., LAUT, V. M. \& MENTZINGEN, L. G. 2012. Foraminíferos do Complexo Sepetiba/Guaratiba. In: RODRIGUES, M. A. C., PEREIRA, S. D. \& SANTOS S. B. (eds.), Baía de Sepetiba - Estado da Arte. Corbã, Rio de Janeiro, pp. 115-50.

LAUT, L. L. M., RODRIGUES, M. A. C., SILVA, F. S., MARTINS, V., CARVALHAL-GOMES, S. B. V., FONTANA, L. F., SOUZA, R. C. C. L., XAVIER, D. S. \& JULIACE, A. C. A. 2014. Foraminíferos como indicadores paleoclimáticos do Quaternário das bacias marginais brasileiras. In: CARVALHO, I. S., GARCIA, M. J., LANA, C. C. \& STROHSCHOEN, O. JR. (eds.), Paleontologia: Cenário de Vida - Paleoclimas. Interciência, Rio de Janeiro, pp. 525-549.

LEROY, D. O. \& HODGKINSON, K. A. 1975. Benthonic foraminifera and some Pteropoda from a deep-water dredge sample, northern Gulf of Mexico. Micropaleontology, 21, 4, 420-447.

LOEBLICH, A. R. JR. \& TAPPAN, H. 1988. Foraminiferal genera and their classification, Van Nostrand Reinhold Company, New York, NY.

LOEBLICH, A. R. JR. \& TAPPAN, H. 1994. Foraminifera of the Sahul Shelf and Timor Sea. Cushman Foundation Special Publication, 31, 1-661.

MAGURRAN, A. E. \& MCGILL, B. J. 2011. Biological diversity - frontiers in measurement and assessment, Oxford University Press, Oxford.

MILKER, Y. \& SCHMIEDL, G. 2012. A taxonomic guide to modern benthic shelf foraminifera of the Western Mediterranean Sea. Palaeontologia Eletronica, 15, 2, 1-16

MURRAY, J. 2006. Ecology and applications of benthic foraminifera, Cambridge University Press, Cambridge.

NATHAN, S. A., LECKIE, R. M. \& MABEE, S. B. 2014. Benthic foraminifera of the western Gulf of Maine 60 years later: a pilot study comparing changes in species distributions. Journal of Foraminiferal Research, 44, 3, 230-254.

PAYNE, R. J., LAMENTOWICZ, M. \& MITCHELL, E. A. D. 2011. The perils of taxonomic inconsistency in quantitativa palaecology: experiments with testatbe amoeba data. Boreas, 40, 17, 15-27.

PANCHANG, R. \& NIGAM, R. 2014. Benthic ecological mapping of the Ayeyarmady delta shelf off Myanmar, using foraminiferal assemblages. Journal of the Palaeontological Society of India, 59, 2, 121-168.

PASSOS, C. C., KUKIMODO, I. \& SEMENSATTO, D. 2017. Foraminiferal assemblages along the intertidal zone of Itapanhaú River, Bertioga (Brazil). Journal of South American Earth Sciences, 79, 297-306.

PAWLOWSKI, J., ESLING, P., LEJZEROWICZ, F., CORDIER, T., VISCO, J. A., MARTINS, C. I. M., KVALVIK, A., STAVEN, K. \& CEDHAGEN, T. 2016. Benthic monitoring of salmon farms in Norway using foraminiferal metabarcoding. Aquaculture Environment Interactions, 8, 371-386.

PAWLOWSKI, J., LEJZEROWICZ, F. \& ESLING, P. 2014. Next-generation environmental diversity surveys of foraminifera: preparing the future. The Biological Bulletin, 227, 2, 93-106.

REVETS, S. A. 2005. A key to the unilocular hyaline Foraminifera. Journal of Micropaleontology, 24, 145-158.

RHUMBLER, L. 1935. Rhizopoden der Kieler Bucht, gesammelt durch A. Remane I. Teil. Naturwissenschaftlichen Vereins für Schleswig-Holstein, 21, 2, 143-194.
RUDORFF, N. M. 2008. Comparação biossedimentológica entre sítios de cultivo de moluscos marinhos sob influência de diferentes condições hidrodinâmicas: estudo aplicado à Baía Sul, Ilha de Santa Catarina (SC). Masters thesis, Federal University of Santa Catarina, Florianópolis, Brazil, viewed 20 March 2020, <http://repositorio.ufsc.br/xmlui/handle/123456789/91257>.

SABEAN, J. A. R., SCOTT, D. B., LEE, K. \& VENOSA, A. D. 2009. Monitoring oil spill bioremediation using marsh foraminifera as indicators. Marine Pollution Bulletin, 59, 8-12, 352-361.

SANTA-CRUZ, J. 2004. Foraminiferos atuais em um manguezal impactado por petróleo 20 anos atrás: Rio Iriri, Canal de Bertioga, Santos-SP. Masters thesis, State University of São Paulo, Rio Claro, Brazil, viewed 15 March 2020, <http://hdl. handle.net/11449/92833>.

SCOTT, D. B., MEDIOLI, F. S. \& SCHAFER, C. T. 2001. Monitoring in coastal environments using foraminifera and thecamoebian indicators, Cambridge University Press, Melbourne, NY.

SEMENSATTO, D. L. JR. \& DIAS-BRITO, D. 2004. Análise ambiental de uma área parálica no delta do Rio São Francisco, Sergipe-Brasil, com base na sinecologia de foraminíferos e tecamebas (Protista). Revista Brasileira de Paleontologia, 7, 1, 53-66.

SEMENSATTO, D. L. JR., FUNO, R. H., DIAS-BRITO, D. \& COELHO, C. JR. Foraminiferal ecological zonation along a Brazilian mangrove transect: Diversity, morphotypes and the influence of subaerial exposure time. Revue de Micropaleontologie, 52, 1, 67-74.

SEMENSATTO, D. L. JR., OLIVEIRA, D. \& DIAS-BRITO, D. 2008. Blysmasphaera broennimanni: a new recent allogromiine species (Order Foraminiferida, Eichwald, 1830) from Brazil. Revue de Paléobiologie, 27, 2, 525-531.

SEN-GUPTA, B. 2003. Systematics of modern foraminifera. Modern foraminifera. Springer-Verlag, Dordrecht, Netherlands.

SIEMENSMA, F., APOTHÉLOZ-PERRET-GENTIL, L., HOLZMANN, M., CLAUSS, S., VÖLCKER, E. \& PAWLOWSKI, J. 2017. Taxonomic revision of freshwater foraminifera with the description of two new agglutinated species and genera. European Journal of Protistology, 60, 28-44.

SMITTER, Y. H. 1956. Chitinosaccus, a new foraminiferal genus of the allogromiidae from Santa Lucia Bay, Zululand. South African Journal of Science, 56, 11, 258-259.

TODD, R. \& LOW, D. 1981. Marine flora and fauna of the northeastern United States. Protozoa: Sarcodina: benthic foraminifera. NOAA Technical Report NMFS Circular 439.

VINK, C. J., PAQUIN, P. \& CRUICKSHANK, R. H. 2012. Taxonomy and irreproducible biological science. Bioscience, 62, 5, 451-452.

WAŚKOWSKA, A. \& KAMINSKI, M. A. 2019. Pleistocene epilithic foraminifera from the Arctic Ocean. Peer J, 7, 6, e7207.

WU, R. S. S. 1982. Effects of taxonomic uncertainty on species diversity indices. Marine Environment Research, 6, 3, 215-225.

YANKO, V., ARNOLD, A. J. \& PARKER, W. C. 2003. Effects of Marine Pollution on Benthic Foraminifera. In: SEN GUPTA, B. (ed.), Modern foraminifera, Kluwer Academic Publishers, Dordrecht, Netherlands, pp. 217-235.

ZANINETTI, L., BRÖNNIMANN, P., BEURLEN, G. \& MOURA, J. A. 1977. La mangrove de Guaratiba et la baie de Sepetiba: état de Rio de Janeiro, Brésil: foraminifères et écologie. Archives Sciences Genève, 30, 2, 161-178. 
ZANINETTI, L., BRONNIMAN, P., DIAS-BRITO, D., ARAI, M., CASALETTI, P., KOUTSOUKOS, E. \& SILVEIRA, S. 1979. Distribution écologique des Foraminifères dans la Mangrove d'Acupe, Etat de Bahia, Brésil. Notes du Laboratoire de Paleontologie de L'Université de Genève, 4, 1, 1-17.
ZERFASS, G. S. A., ANDRADE, E. J., LESSA, G. C. \& MACHADO, A. J. 2006. Foraminíferos bentônicos do estuário de Cacha-Prego Ilha de Itaparica, Bahia, Brasil. Pesquisas em Geociências, $33,2,43-54$ 